\title{
$\beta$-Glucans Production of Saccharomyces cerevisiae by Using Tofu Waste as Animal Feed Supplement
}

\author{
Endah Rita Sulistya Dewi*, Ary Susatyo Nugroho, Atip Nurwahyunani, Maria Ulfah \\ Departement of Mathematics, Sciences and Information Technology, Universitas PGRI Semarang, Indonesia \\ *Corresponding Author: endahrita@yahoo.co.id
}

Submitted: 2020-10-20. Revised: 2020-12-18. Accepted: 2021-03-07

\begin{abstract}
Tofu industrial waste has the potential to become contaminant when it is not maximum processed, so it needs appropriate treatment to minimize the occurrence of pollution. $\beta$-Glucans can be produced from the yeast cell wall of Saccharomyces cerevisiae.As a feed supplement, $\beta$-Glucans have been used for an immunostimulant because it can increase the immune system. This study aimed to establish a suitable technology to produce $\beta$-Glucans fromSaccharomyces cerevisiae by utilize tofu waste as feed supplement. The Completely Randomized Design (CRD) model was used in the experimental method. This study used an experimental method with a Completely Randomized Design (CRD) model.The treatment given wereP1: $1 \mathrm{~kg}$ of tofu waste $+1 \mathrm{~kg}$ of bran $+0.2 \mathrm{~kg}$ fish meal $+0.2 \mathrm{lt}$ molasses $+5.5 \mathrm{gSaccharomyces}$ cerevisiae; $\mathrm{P} 2: 1 \mathrm{~kg}$ of tofu waste $+1 \mathrm{~kg}$ of bran $+0.2 \mathrm{~kg}$ fish meal $+0.2 \mathrm{lt}$ molasses $+6.5 \mathrm{~g}$ Saccharomyces cerevisiae; P3: $1 \mathrm{~kg}$ of tofu waste $+1 \mathrm{~kg}$ bran $+0.2 \mathrm{~kg}$ fish meal $+0.2 \mathrm{lt}$ molasses $+7.5 \mathrm{~g}$ Saccharomyces cerevisiae. Each treatment was repeated 3 times, and fermented for five days.The results found that P1 by Saccharomyces cerevisiae $5.5 \mathrm{~g}$ was the best formulation to produced crude $\beta$-Glucans by weight of $25.9 \mathrm{~g} / \mathrm{kg}$ of waste. Production of $\beta$-Glucans as an animal feed supplement is a waste-based feed technology development which is expected to increase livestock production both in quality and quantity.
\end{abstract}

Key words: tofu waste; $\beta$-Glucans; Saccharomyces cerevisiae

How to Cite: Dewi, E. R. S., Nugroho, A. S., Nurwahyunani, A., \& Ulfah, M. (2021). ß-Glucans Production of Saccharomyces cerevisiae by Using Tofu Waste as Animal Feed Supplement. Biosaintifika: Journal of Biology \& Biology Education, 13(1), 65-69.

DOI: http://dx.doi.org/10.15294/biosaintifika.v13i1.26754

\section{INTRODUCTION}

The tofu industry is one industry with large waste production. The waste produced is liquid waste or solid waste, which if dumped directly into the environment will result in a very large impact of environmental pollution. The very high content of organic material allows the oxidation process of organic matter by microorganisms in water bodies. The process will use dissolved oxygen in water, so that ultimately the availability of oxygen for life in the environment decreases. This can bring the death of living things in. Tofu waste is used as a substrate for the growth of Saccharomyces cerevisiae, while sugar cane waste is used as a source of glucose to increase production of Saccharomyces cerevisiae cells (Mufarida \& Probowulan., 2019). The use of waste is also intended as an effort to minimize the occurrence of environmental pollution.The solid waste of the tofu processing plant is in the form of soybean cleaning (rock, soil, soybean skin, and other solid objects attached to soybeans) and the rest of the soybean slurry called tofu pulp.

Saccharomyces cerevisiae has cell walls containing $\beta$-D-Glucans, chitin, and manoprotein. The cell walls are known to consist of three layers: the inner layer is alkaline insoluble $\beta$-Glucans (30$35 \%$ ), the middle layer is alkali-soluble $\beta$-Glucans $(20-22 \%)$, and the outer layer is glycoprotein $(30 \%)$ namely carbohydrates arranged from manan phosphorylated (Hwanget al., 2018). Saccharomyces cerevisiae can be grown in the laboratory by growing it on certain media, both solidand liquid media. The macroscopic appearance is rounded, colonized, whitish-colored, the surface is shiny, smooth, soft texture, and has round cells with acropora 1-8 pieces. Judging from the cell wall, Saccharomyces cerevisiae has cell walls containing $\beta$-D-Glucans, chitin, and manoprotein ( $\mathrm{Li}$ et al., 2018). $\beta$-Glucans included inGenerally Recognized as Safe (GRAS) and included in the categories that does not cause side effects and poisonous (Tjokrokusumo, 2015).

To produce $\beta$-Glucans from microbes, several things that can affect the product producedshould be noted. Things that must be considered include the selection of microbial strains, nutrition, and production processes. Microorganism microbial strain is the key to the success of a fermentation, microorganisms must have several advantages needed for the success of a biological process (Stier et al., 2014). In the pharmaceutical industry, $\beta$-Glucans were used for anti-infection, wound-healing, antitumors, antioxidants, and reduce blood sugar levels because it increases insulin production (Peter et al., 2018).

Saccharomyces cerevisiae as the chosen organism, is based on the nature of the microorganism which is able to grow well and is very adaptive in waste media 
with minimal nutrition such as non dairy creamer media (Dewi et al., 2016). Feed supplements are additional essential food ingredients that are useful for stimulating growth and preventing disease, as well as improving the quality of rations. The findings targeted in this study are new appropriate technologies, namely waste-based "feed supplement" products containing $\beta$-Glucansthat can be accepted and applied by farmers to increase fish production. Research on feed supplements has been carried out. However, existing fermentation technology innovations have not maximally been able to produce feed supplements that are rich in $\beta$-Glucans as fish immunostimulants. Therefore, it is necessary to develop waste product based feed technology as a first step in producing feed supplements that are low cost, and environmentally friendly. The purpose of this study was to determine the right concentration of Saccharomyces cerevisiae which can contribute optimally to the production of $\beta$-Glucans in wastebased feed supplements.

\section{METHOD}

\section{Feed Formulation}

The tofu dregs used in this study are pulp obtained from the tofu industry process. The tofu waste is still wet with a water content of about $85-90 \%$.This study used an experimental method with a Completely Randomized Design (CRD) model. The treatment given wereP1: $1 \mathrm{~kg}$ of tofu waste $+1 \mathrm{~kg}$ of bran +0.2 $\mathrm{kg}$ fish meal $+0.2 \mathrm{lt}$ molasses $+5.5 \mathrm{~g}$ Saccharomyces cerevisiae; $\mathrm{P} 2: 1 \mathrm{~kg}$ of tofu waste $+1 \mathrm{~kg}$ of bran +0.2 $\mathrm{kg}$ fish meal $+0.2 \mathrm{lt}$ molasses $+6.5 \mathrm{~g}$ Saccharomyces cerevisiae; $\mathrm{P} 3$ : $1 \mathrm{~kg}$ of tofu waste $+1 \mathrm{~kg}$ bran $+0.2 \mathrm{~kg}$ fish meal $+0.2 \mathrm{lt}$ molasses $+7.5 \mathrm{~g}$ Saccharomyces cerevisiae. Each treatment was repeated 3 times, and fermented for five days.

\section{$\beta$-Glucans extraction.}

Thirtyml of culture samples were centrifuged at $7000 \mathrm{rpm}$ for 20 minutes at $15^{\circ} \mathrm{C}$. Supernatants were removed, cell biomass pellets were added with $5 \mathrm{~mL}$ $2 \% \mathrm{NaOH}$ then heated for 5 hours at $90^{\circ} \mathrm{C}$. The cell biomass suspension was centrifuged again at a speed of $5000 \mathrm{rpm}$ for 10 minutes. The supernatant obtained was added with $\mathrm{CH}_{3} \mathrm{COOH} 2 \mathrm{M}$ drop by drop until the $\mathrm{pH}$ of the solution was around 6.8-7, then it was precipitated with 3 volumes of ethanol. The precipitate formed was separated by centrifugation at a speed of $5000 \mathrm{rpm}$ for 10 minutes. Separate pellets weredried, then weighed as rough $\beta$-Glucans weights.

\section{Cell dry weight}

The preparation of Saccharomyces cerevisiae cell powder was based on the method of Amaria et al.,
(2007). Saccharomyces cerevisiae cells were harvested at optimal growth by doing $3000 \mathrm{rpm}$ centrifugation 2 times each for 10 minutes. The precipitate was washed by means of distilled water and filtered with Whatman filter paper No.40. The cells were then dried at $50-60^{\circ} \mathrm{C}$ for 3 days. After drying, cell grinding wasdone, then the powder produced wasweighed by the cell dry weight.The culture sample was taken on the fifth day after Solid State Fermentation (SSF) fermentation was carried out. SSF is a fermentation process using an insoluble (solid) substrate. The substrate wasfermented with microorganisms under conditions of lack of water. Thewater content used waslow at around 50-60\%. Twelvehours after 48-hour of fermentation time, the condition of the steamy fermentor indicatedthat the fermentation process has occurred.

\section{RESULT AND DISCUSSION}

Based on Variety Analysis, F $<F$ Table at the confidence level of $5 \%$, itcan be stated the treatment of variations in concentration of Saccharomyces cerevisiae did not affect the weight of the wastebased $\beta$-Glucans. however, the best waste-based $\beta$ Glucans formulation from the average treatment in the combination of waste and Saccharomyces cerevisiae 5.5 gr. From the formulation it produced a crude $\beta$-Glucans weight of $25.9 \mathrm{gr} / \mathrm{kg}$ of waste in treatment P1.

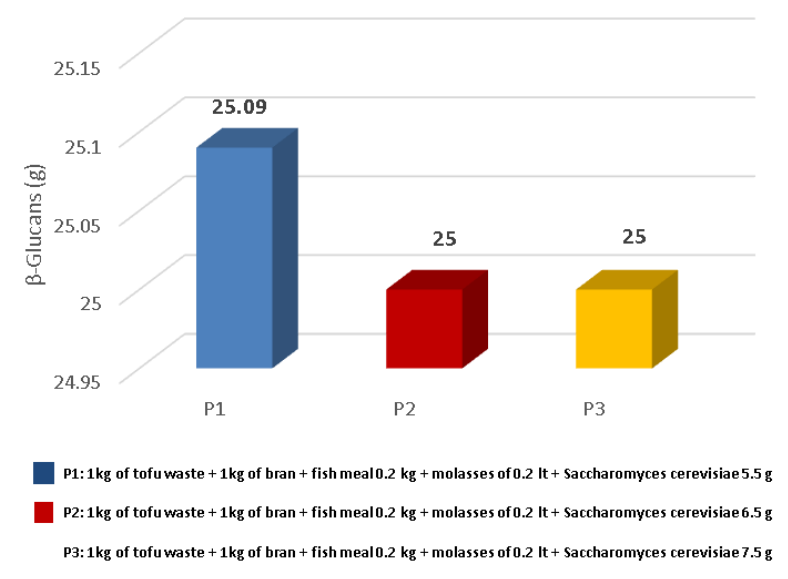

Figure 1. Weight of $\beta$-Glucans by various formulations of Saccharomyces cerevisiae (P1, P2, and P3 formulations).

Levels of $\beta$-Glucans in culture tended to increase at the beginning of fermentation and relative constant at the end of fermentation time. The results showed that the highest of $\beta$-Glucans weights was obtained at $5.5 \mathrm{~g}$ of Saccharomyces cerevisiae. This results implied that yeast can grow optimally in waste media consisting of tofu waste and molasses. While, when the yeast is added more than $5.5 \mathrm{~g}$, the production of 
$\beta$-Glucans will decrease significantly. Mukhtar et al., (2010), stated that high yeast concentration could cause shorter fermentation process, and the consequence is the viability of cells will decrease after log phase. Growth and metabolic conditions in high cell populations are not expected because they interfere with access to nutrients, space limitations and interactions between cells. Dewi, et al., (2016) mentioned that administration of an inoculum on non dairy creamer wastewater media with a concentration of $10^{8}$ provide lower protein contents compared to administration of inoculums on waste-basedmedia. However, Agbogbo et al. (2007) in his research mentioned that administration an inoculums at low concentration provide slow rate fermentation process, but produce a higher product due to in this condition the cells have ability to proliferate itself. Mukhtar et al. (2010), mentioned that the addition of Saccharomyces at higher concentration in ethanol production tends to decrease fermentation process, and reduce cells viabilities after log phase. Growth and metabolic conditions in high cell populations are not expected because they interfere with access to nutrition, space limitations and interactions between cells. The cell weight of Saccharomyces between 6.5 and $7.5 \mathrm{~g}$ in media can reduce $\beta$-Glucans production. On the contrary, the higher cell population of Saccharomyces in waste media vice versa.

Molasses are by products derived from the manufacture of sugar cane (Saccharum officinarum L). Molasses still contains high levels of sugar from $50-60 \%$, amino acids, and minerals. Giving molasses to fermentation media is important for the growth of microorganisms. Glucose as the main carbon source is absorbed through the active transfer process which is then metabolized to produce energy and synthesize cell-forming materials, as well as metabolite synthesis, while the nitrogen source in fermentation media is used for protein synthesis in cells (Farida,2019).

The protein content in tofu waste becomes an important component to support microbial growth, in this case Saccharomyces cerevisiae, including in the formation of cell membranes.According to Nasseri et al. (2011), the Saccharomyces cerevisiae cell membrane consists of lipoprotein, which contains enzymes needed for the synthesis of some components of the cell wall. The enzymes found in Saccharomycescerevisiae cells include proteases, carboxypeptidase, aminopeptidase, and intervase (Dewi, E R S., 2016). With the presence of these enzymes, Saccharomyces cerevisiae can use the waste medium as a growth medium.

$\beta$-Glucans can be extracted from the Saccharomyces cerevisiae cell wall through alkaline extraction. However, to obtain pure $\beta$-Glucans it needs a further purification. Alkaline extraction is based on $\beta$-Glucans properties which are easily soluble in alkalis. $\beta$-Glucans is extracted using $\mathrm{NaOH}$ with the help of heat, then it is precipitated in ethanol to obtain rough $\beta$-Glucans. $\beta$-Glucans is known to have antimicrobial and antitumor activity by increasing host immune function, and activating macrophages and neutrophils by binding to $\beta$ Glucans receptors (Yuan et al. 2019). $\beta$-Glucans is also reported to have various immune system stimulation activities that are influenced by its structure such as molecular weight, degree of branching, and its conformation (Ho et al., 2016; Dietrichet al. 2011; Di Domenico et al, 2017).The primary structure of $\beta$-Glucans macromolecule is presented in Figure 2 below.

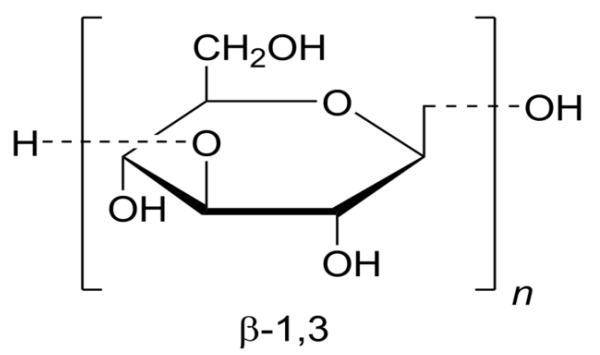

Figure 2. Primary structure of $\beta$-Glucans macromolecules. (Sima et al., 2018)

$\beta$-Glucans produced from tofu waste fermentation can be a source of immunity because of its potential as anti-microbial properties. Polysaccharide krestin (PSK) from Coriolusversicolor extract contains $\beta$ glucan that can increase phagocytic activity and capacity.Polysaccharide krestin (PSK) has potential as a stimulator that can activate immunocompetent cells to increase the immune system (Wahyuningsih, S.P.A, 2016).

Product growth and formation by microorganisms used is the process of converting nutrients into cell mass and the formation of metabolite products in the fermentation process (Didu, 2010). Substrate particle size in the Solid State Fermentation (SSF) method is one of the factors that influence the fermentation process, it affects the surface area to the volume ratio of substrate particles utilized by microorganisms (Jayus et al, 2017). The culture sample was taken on the fifth day after Solid State Fermentation (SSF) fermentation was carried out Saccharomyces cerevisiae were fermented for 5 days, from lag phase (at $0 \mathrm{hr}$ ) till death phase (at $120 \mathrm{hr}$ ). The treatment given were $\mathrm{P} 1: 1 \mathrm{~kg}$ of tofu waste $+1 \mathrm{~kg}$ of bran +0.2 $\mathrm{kg}$ fish meal $+0.2 \mathrm{lt}$ molasses $+5.5 \mathrm{~g}$ Saccharomyces cerevisiae; $\mathrm{P} 2$ : $1 \mathrm{~kg}$ of tofu waste $+1 \mathrm{~kg}$ of bran +0.2 $\mathrm{kg}$ fish meal $+0.2 \mathrm{lt}$ molasses $+6.5 \mathrm{~g}$ Saccharomyces cerevisiae; $\mathrm{P} 3$ : $1 \mathrm{~kg}$ of tofu waste $+1 \mathrm{~kg}$ bran $+0.2 \mathrm{~kg}$ fish meal +0.2 lt molasses +7.5 gSaccharomyces 
cerevisiae. Each treatment was repeated 3 times, and fermented for five days presented in Figure 3.

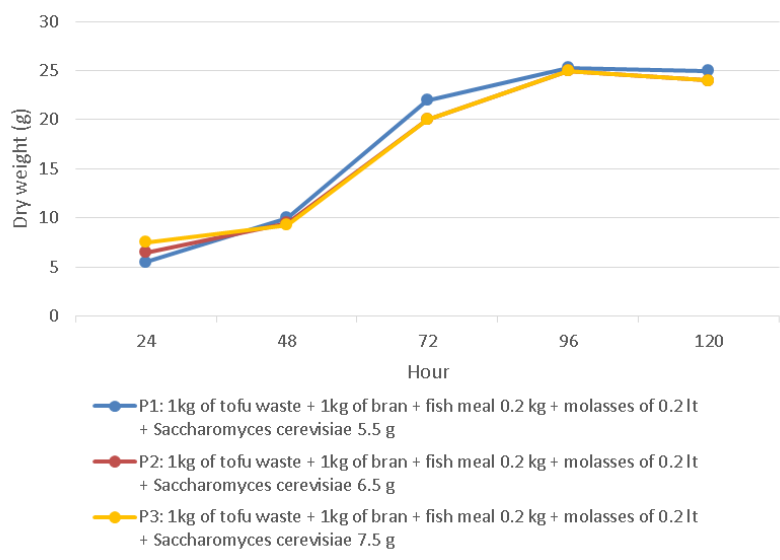

Figure 3. Dry weight ofcells at various concentration of Saccharomyces cerevisiaeusing tofu waste media after 5 days fermentation.

The results showed that all concentrations of inoculums have the same growth pattern (Figure 3). The results also showed that tofu waste media can cause prolong of log phase ( 3 days). This condition is caused by tofu waste that still containing protein, fat, and carbohydrates needed by microbes for its growth. Dewiet al. (2017) mentioned that Non Dairy Creamer media concentration of $75 \%$ contains carbohydrate, fat, and protein components which are suitable for the growth of microorganisms in this case Saccharomyces cerevisiae which performs a series of metabolic processes.

The Figure 3 also mentioned that the lag phase in the first 24 hours immediately occurredafter inoculation when the cells were growth on tofu waste media. Saccharomyces cerevisiaerecognize their molecular components when absorbing new nutrients from waste of tofu. The compositions and type of nutrients of tofu waste media will affect the type of enzyme synthesized, the required enzyme will be formed, the enzyme that is not needed will be suppressed (Dewi et al., 2017). The "machine" process in the cell adapts to new environmental conditions. This change will be reflected in the cell mechanism through regulating the metabolic process. During this phase the cell mass increases slightly without changing cell density. The lag phase period is very dependent on the age of the inoculum. The optimum inoculum will produce a minimum lag phase. To shorten the lag phase, cells must be grown on the media and optimum growth conditions, cells must be active, and the volume of inoculum ranges from $5 \%$ to $10 \%$ (Thierie, 2018).

In the exponential phase (log phase), the cell has adapted to its new environment. Cells will grow rapidly, so that the cell mass and the number of cells will increase exponentially with time, there will be a balance growth that is all the components in the cell grow at the same speed. The composition of a cell is nearly constant.In balance growth, the specific growth rate will be the same whether determined by cell mass or cell number. The concentration of nutrients in this phase is large, so the growth rate is not affected by nutrient concentration. The growth rate in the exponential phase follows first order differential equations (Thierie, 2018).

After 96 hours, the dry weight of the cells produced beganto decline, this results indicated that Saccharomyces cerevisiaehadentered to the stationary phase. In this phase, microorganisms that multiply less than the dead microorganisms, causes the decrease nutrient concentration also causes a decrease in reproductive ability. According to Masturi et al.(2017), the decrease in ethanol concentration occurred until 36 hoursfermentation time, in line with the cell population continuation. In this pattern, the specific growth rate of microorganisms is directly proportional to the rate of formation of the product produced.During the fermentation process, the composition of the substrate changes every time and the metabolite product will be formed. The environmental conditions of the growth ofSaccharomyces cerevisiae are in an unsteady state condition.

This research are expected to significantly contribute to: (1) support the National Food Security Program which was launched by the Indonesian Government, (2) strengthen and enrich the feed technology by waste product-based, and (3) produce environmentally friendly feed supplement.

\section{CONCLUSION}

Based on the results of the study it can be concluded that tofu waste can be used as a medium for producing $\beta$-Glucans from Saccharomyces cerevisiae. P1 treatment is the best formulation combination between tofu waste media and Saccharomyces cerevisiaeto produce of $\beta$-Glucans andit can produce $\beta$-Glucans as much as $25.9 \mathrm{~g} / \mathrm{kg}$ tofu waste.

\section{REFERENCES}

Agbogbo, F.K., Kelly, G.C., Smith, M.T., Wenger, K. And Jeffries, T.W. (2007).The Effect Initial Cell Concentration on Xylose Fermentation by Pichiastipitis. Journal of Applied Biochemistry and Biotechnology, 41, 2331-2336.

Amaria, Agustini, R., Cahyaningrum, S.E., Santosa, S.J dan Narsito. (2007). Adsorbsi Seng (II) Menggunakan Biomassa Saccharomyces 
cereviceae yang Diimobilisasi pada Silika Secara Sol Gel. Akta Kimindo. 2 (2), 63-74

Dewi, E R S., Anang M. LegowodanMunifatulIzzati. (2016). Absorption of Organic Compounds by Saccharomyces cerevisiae on Industrial Waste Media. International Journal of Applied Environmental Sciences. 11 (1), 27-34

Dewi, E R S., Anang M. Legowo, MunifatulIzzati. (2017). The Use of Non Dairy Creamer Wastewater As The Growth Medium OfSaccharomyces cerevisiae For Single-Cell Protein Production. Advance Science Letters. 23 (3),2438-2440

Di Domenico, J., Canova, R., Soveral, L, F., Nied, C, O., Costa, M, M., Frandoloso, R., Kreutz, L, C. (2017). Immunomodulatory effects of dietary $\beta$ glucan in silver cat fish (Rhamdia quelen). Pesquisa Veterinária Brasileira. 37(1): 73-78.

Didu,Nurhidayah.(2010).Produksi Bioetanol dari Sirup Glukosa Ubi Jalar (IpomeabatatasL) dengan Menggunakan Saccharomyces cerevisiae, Institut Pertanian Bogor.

Dietrich Muszalska, A., Olas, B., Kontek, B., Rabe Jablonska, J., (2011). Beta-glucan from Saccharomyces cerevisiae reduces plasma lipid peroxidation induced by haloperidol. International Journal of Biological Macromolecules. 49, 113116.

Farida. (2019). Analisis Biaya dan Nilai Tambah Pengolahan Wine Molase Tebu di Karang Asem Bali. Jurnal Riset Manajemen dan Bisnis (JRMB) Fakultas Ekonomi UNIAT. 4 (3), 339-348

Ho, H. V., Sievenpiper, J. L., Zurbau, A., Blanco Mejia, S., Jovanovski, E., Au Yeung, F., Jenkins, A. L, Vuksan, V. (2016). The effect of oat $\beta$ glucan on LDL cholesterol, non HDL cholesterol and apoB for CVD risk reduction: A systematic review and meta analysis of randomised controlled trials. British Journal of Nutrition. 116 (8), 1369-1382.

Hwang Jangsun, Kyungwoo Lee, Assaf. A. Gilad \& Jonghoon Choi. (2018). Synthesis of Beta-glucan Nanoparticles for the Delivery of Single Strand DNA. Biotechnology and Bioprocess Engineering. 23,144-149

Jayus, Jay., Sony Suwasono, Ike Wijayanti. (2017). Produksi Bioetanol secara SHF dan SSF Menggunakan Aspergillus niger, Trichoderma viride dan New Aule Instant Dry Yeast pada Media Kulit Ubi Kayu. Jurnal Agroteknologi. 11 (1), 61-68.

Li, F., Wang, Z., Liu, J., Li, W., (2018). Radioprotective effect of orally administered beta- d-glucan derived from Saccharomyces cerevisiae. International Journal of Biological Macro molecules. 115, 572- 579.

Masturi, Amelia Cristina, Nurul Istiana, Sunarno, Pratiwi Dwijananti. (2017). Ethanol Production from Fermentation of Arum Manis Mango Seeds (Mangifera indica L.) using Saccharomyces cerevisiae. Jurnal Bahan Alam Terbarukan. 6 (1), 56-60.

Mufarida and Diyah Probowulan. (2019).Optimization and Utilization of Tofu Waste by Using Separator Machine Technology to Increase the Income of Home Industries and Create Environment-Friendly Industries Through Diversification of Various Foods Processing. Kontribusia. 2 (2) , 48-52.

Mukhtar, K., Asgher, M., Afghan, S., Hussain, K. And Zia-ul-Hussnain, S. (2010).Comparative Study on Two Commercial Strain of Saccharomyces cerevisiae for Optimum Ethanol Production on Industrial Scale.Journal of Biomedicine and Biotechnology, 1-5.

Peter, MJ. Casado, Bedmar M. (2018). A B-Glucan Based Dietary Fiber Reduces Mast Cell-Induced Hyperpermeability in Ileum From Patients with Crohn's Disease and Control Subjects. Inflammatory Bowel Diseases. 24 (1) ,166-178.

Sima, Petr., Luca Vannucci, Vaclav Vetvicka. (2018). $\beta$-glucans and cholesterol. International Journalof Molecular Medicine. 41 (4), 17991808.

Stier H, Ebbeskotte V, Gruenwald J. (2014). Immune-modulatory effects of dietary Yeast Beta1,3/1,6-D-glucan. Nutr Journal, 13, 38.

Thierie, Jacques. (2018). Mathematical Modeling of Growth Lag Phase Formulated on the Basis of Mass and Number of AxenicMicrobial Cells in a Population. EC Microbiology 14(9), 552-566.

Tjokrokusumo, Donowati. (2015). Diversity of Edible Mushrooms on their Beta Glucans Content and Health Benefits. Prossiding Seminar Nasional Masyarakat Biodiversitas Indonesia. 1(6) ,15201523.

Wahyuningsih, S PA., Nadyatul Ilma Indah Savira, and Win Darmanto. (2016). Effect on Polysaccharide Krestin from Coriolus versicolor Extract onPhagocytic Activity and Capacity of Mus musculus Exposed byPseudomonas aeruginosa. Biosaintifika 8 (3), 308-313.

Yuan, B., Ritzoulis, C., Chen, J. (2019). Rheological investigations of beta glucans functionality: Interactions with mucin. Food Hydrocolloids. 87,180-186. 